\title{
ACTIVITY OF ESSENTIAL OILS OF Lippia alba CHEMOTYPES AND THEIR MAJOR MONOTERPENES AGAINST PHYTOPATHOGENIC FUNGI
}

\author{
ATIVIDADE DOS ÓLEOS ESSENCIAIS DE QUIMIOTIPOS DE Lippia alba E SEUS \\ MONOTERPENOS MAJORITÁRIOS SOB FUNGOS FITOPATOGÊNICOS
}

\section{Magna Galvão PEIXOTO'; ${ }^{1}$ Arie Fitzgerald Blank² ${ }^{2}$ Maria de Fátima ARRIGONI-BLANK²; Paulo Roberto GAGLIARDI ${ }^{2}$; Juliana Oliveira de MELO $^{3}$; Daniela Aparecida de Castro NIZIO $^{3}$; Vanderson Santos PINTO ${ }^{4}$}

1. Professor, Doutor, Campus de Lagarto/UFS, Lagarto, SE, Brasil; 2. Professor, Doutor, Departamento de Engenharia Agronômica, UFS, São Cristóvão, SE, Brasil. arie.blank@ gmail.com; 3. Doutora em Biotecnologia, Universidade Federal de Sergipe - UFS, São Cristóvão, SE, Brasil. 4. Mestre em Agricultura e Biodiversidade, Universidade Federal de Sergipe - UFS, São Cristóvão, SE, Brasil.

\begin{abstract}
This work aimed to evaluate the in vitro antifungal activity of the essential oils of $L$. alba belonging to the carvone chemotype (LA-13 and LA-57) and the citral chemotype (LA-10, LA-29, and LA-44); the carvone enantiomers $(R)-(-)$-carvone and $(S)-(+)$-carvone; and citral on phytopathogenic fungi Lasiodiplodia theobromae (LT), Fusarium pallidoroseum (FP) and Fusarium solani (FS). Concentrations of $0.01 ; 0.05 ; 0.1 ; 0.2 ; 0.3 ; 0.5$ and 1.0 $\mathrm{mL} / 100 \mathrm{~mL}$ were tested, and the percentage of mycelial growth inhibition (MGI) was calculated after 96h in relation to the control. Minimal Inhibitory Concentrations (MIC) and Minimal Fungicide Concentrations (MFC) were obtained for essential oils and compounds. From the concentration of $0.2 \mathrm{~mL} / 100 \mathrm{~mL}$, all the accessions and carvone enantiomers were effective against the fungus LT, except the accession LA-44, for which the maximum inhibition occurred from the concentration of $0.3 \mathrm{~mL} / 100 \mathrm{~mL}$. Citral was the most effective compound against LT, with $100 \%$ of MGI from the concentration of $0.05 \mathrm{~mL} / 100 \mathrm{~mL}$. All accessions and enantiomers caused $100 \%$ of MGI against FP fungus from the concentration of $0.2 \mathrm{~mL} / 100 \mathrm{~mL}$. Once again, citral stood out by providing the same result as the other treatments from the concentration of $0.1 \mathrm{~mL} / 100 \mathrm{~mL}$. Considering the fungus FS, carvone enantiomers and citral caused $100 \%$ of MGI from the concentration of $0.1 \mathrm{~mL} / 100 \mathrm{~mL}$ while all accessions caused $100 \%$ of MGI from the concentration of $0.2 \mathrm{~mL} / 100 \mathrm{~mL}$. Citral and carvone enantiomers presented the lowest MIC values $(0.1 \mathrm{~mL} / 100 \mathrm{~mL})$ against FS fungus. The MIC of citral for LT and FP were not determined at the concentrations tested. $(R)-(-)$-carvone enantiomer presented the lowest MIC $(0.1$ $\mathrm{mL} / 100 \mathrm{~mL}$ ) for the LT fungus. Most of the other accessions presented MIC of $0.2 \mathrm{~mL} / 100 \mathrm{~mL}$ for the three fungi. In relation to the minimum fungicidal concentration (MFC), citral stood out with values from $0.05 \mathrm{~mL} / 100 \mathrm{~mL}$ (LT). Citral and carvone presented the same MFC for FS $(0.2 \mathrm{~mL} / 100 \mathrm{~mL})$. The other accessions showed MFC values from 0.3 $\mathrm{mL} / 100 \mathrm{~mL}$ for the three fungi. Essential oils of $L$. alba accessions, carvone enantiomers, and citral were efficient in phytopathogen control and could be considered as an alternative to fungicides for presenting inhibitory and fungicidal effect against these microorganisms at low concentrations.
\end{abstract}

KEYWORDS: Brazilian lemon balm. Major compounds. Lasiodiplodia theobromae. Fusarium pallidoroseum. Fusarium solani.

\section{INTRODUCTION}

Phytopathogenic fungi control has been considered as one of the greatest challenges for agriculture over the years. Despite the effective use of synthetic fungicides, their continuous and indiscriminate application results in several consequences to the environment and human health,, including the contamination of surface and groundwater (FERNANDES-NETO; SARCINELLI, 2009) and the emergence of pathogen populations resistant to these products (SOYLU et al., 2010; TATEISHI et al., 2014).

The fungi Lasiodiplodia theobromae, Fusarium pallidoroseum, and Fusarium solani stand out among the phytopathogens of agricultural interest. The fungus $L$. theobromae is an opportunistic phytopathogen whose spores are dispersed in the soil. This organism causes diseases in several plant species, both in tropical and temperate regions, resulting in the most varied symptoms, such as rotted trunk in grapevines, decay and fall of immature fruits in citrus, and nuts malformation in Anacardium occidentale (BERTSCH et al., 2013; CIPRIANO et al., 2015). Over the years, the number of diseases caused by this fungus in tropical fruit trees has increased, damaging both the productive and post-harvest systems. Therefore, it represents a threat to fruticulture in Northeast Brazil (FREIRE et al., 2011). The genus Fusarium is one of the most important genera of mycotoxigenic fungi for human and animal feeding (THRANE, 2014). The species $F$. pallidoroseum is a soil fungus that survives on crop residues and is generally considered as a secondary colonizer of plant tissues. They may act 
as a pathogen, causing disease in adult plants and deterioration of maize and cotton seeds, consequently reducing germination rate (TAGNE et al., 2003; WHITT et al., 2014). The phytopathogen $F$. solani is cosmopolitan and can be found in several substrates; it is considered as a pathogen for many species of cultivated plants (LESLIE; SUMMERELL, 2006; AL-SADI et al., 2015). In citrus, this fungus is considered as opportunistic, causing root rot (AL-SADI et al., 2014).

The search for safer, viable and efficient alternative methods of phytopathogenic fungi control is increasingly present in research works, which relate the activity of the compounds extracted from essential oils of plants, such as natural fungicides (DINIZ et al., 2008; MARCHESE et al., 2016). Many medicinal and aromatic plants have antimicrobial properties, higher biodegradability, and are therefore considered to be less harmful to the environment than synthetic fungicides (OOTANI et al., 2011).

The species Lippia alba (Mill.) N.E. Brown, also known as lemon balm, is an aromatic shrub belonging to the family Verbenaceae, widely used throughout South and Central America for various purposes. Studies related to its ethnopharmacology have shown the antimicrobial, analgesic, antiinflammatory, anti-oxidant, and repellent potential present in its essential oils (OLIVEIRA et al., 2006; HENNEBELLE et al., 2008; SHUKLA et al., 2009; MAYNARD et al., 2011; PEIXOTO et al., 2015; LIMA et al., 2016).

The chemical variability of the essential oils of $L$. alba allows its differentiation into several chemotypes, according to the predominance of compounds (JANUZZI, 2011; BLANK et al., 2015). The monoterpenes carvone and citral stand out among the chemical compounds contained in the essential oils of L. alba. Carvone has been used in the food and pharmaceutical industries for its antimicrobial, antifungal, and sprouting inhibition actions (CARVALHO; FONSECA, 2006; MA et al., 2015).

Citral is a mixture of two isomeric acyclic monoterpene aldehydes: geranial (trans-citral, citral A) and neral (cis-citral, citral B). It has a lemon flavor and is widely used in the perfumery, food, and cosmetic industries (HEYDORN et al., 2003; BRITO et al., 2011).

This work aimed to test the in vitro antifungal activity of the essential oils of five $L$. alba accessions belonging to the carvone chemotype (LA-13 and LA-57) and citral chemotype (LA-10, LA-29, and LA-44); the enantiomers $(R)-(-)$-carvone and $(S)-(+)$-carvone; and citral on the phytopathogenic fungi $L$. theobromae, $F$. pallidoroseum, and $F$. solani.

\section{MATERIAL AND METHODS}

Leaves were collected from the Active Germplasm Bank (BAG) of Medicinal Plants of the Federal University of Sergipe (UFS), located at the Research Farm "Campus Rural da UFS", in São Cristóvão, state of Sergipe, Brazil $\left(11^{\circ} 00^{\prime} \mathrm{S}\right.$; $37^{\circ} 12^{\prime} \mathrm{W}$ ), for the extraction of the essential oils of the L. alba accessions LA-10, LA-13, LA-29, LA44, and LA-57 (Table 1). Leaves were manually collected and dried in a forced-air circulation oven at $40^{\circ} \mathrm{C}$ for five days (EHLERT et al., 2006).

Table 1. Identification and origin of Lippia alba accessions of the Active Germplasm Bank of medicinal and aromatic plants of the Federal University of Sergipe (UFS).

\begin{tabular}{llll}
\hline Accession code & Chemotype & Municipality/State of origin & $\begin{array}{l}\text { Voucher number at UFS } \\
\text { herbarium }\end{array}$ \\
\hline LA-13 & Carvone & Fortaleza-CE & 13488 \\
LA-57 & Carvone & Rio Real-BA & 13469 \\
LA-10 & Citral & Brasília-DF & 13495 \\
LA-29 & Citral & Planaltina de Goiás-GO & 13485 \\
LA-44 & Citral & Brasília-DF & 14788 \\
\hline
\end{tabular}

The essential oil was extracted in the Laboratory of Phytotechnology of UFS, by hydrodistillation, using an adapted Clevenger apparatus. Each sample consisted of $75 \mathrm{~g}$ of dried leaves, which were distilled for 120 minutes.

The analysis of the chemical composition of the essential oils was performed using a GCMS/FID (QP2010 Ultra, Shimadzu Corporation, Kyoto, Japan) equipped with an autosampler AOC- 20i (Shimadzu). Separations were accomplished using an Rtx ${ }^{\circledR}-5 \mathrm{MS}$ Restek fused silica capillary column (5\%-diphenyl-95\%-dimethyl polysiloxane) of $30 \mathrm{~m} \times 0.25 \mathrm{~mm}$ i.d., $0.25 \mu \mathrm{m}$ film thickness, at a constant helium (99.999\%) flow rate of $1.2 \mathrm{~mL} / \mathrm{min}$. Injection volume of $0.5 \mu \mathrm{L} \quad(5 \mathrm{mg} / \mathrm{mL})$ was employed, with a split ratio of $1: 10$. The oven temperature was programmed from $50{ }^{\circ} \mathrm{C}$ (isothermal for $1.5 \mathrm{~min}$ ), with an increase of 4 
${ }^{\circ} \mathrm{C} /$ min to $200{ }^{\circ} \mathrm{C}$, then $10{ }^{\circ} \mathrm{C} / \mathrm{min}$ to $250{ }^{\circ} \mathrm{C}$, ending with a $5 \mathrm{~min}$ isothermal at $250{ }^{\circ} \mathrm{C}$.

The MS (Mass Spectrometer) and FID (Flame Ionization Detector) data were simultaneously acquired employing a Detector Splitting System; the split flow ratio was 4:1 (MS:FID). A $0.62 \mathrm{~m} \mathrm{x} 0.15 \mathrm{~mm}$ i.d. restrictor tube (capillary column) was used to connect the splitter to the MS detector while a $0.74 \mathrm{~m} \mathrm{x} 0.22 \mathrm{~mm}$ i.d. restrictor tube was used to connect the splitter to the FID detector. The MS data (total ion chromatogram, TIC) were acquired in the full scan mode $(\mathrm{m} / \mathrm{z}$ of 40-350) at a scan rate of $0.3 \mathrm{scan} / \mathrm{s}$ using the electron ionization (EI) with an electron energy of $70 \mathrm{eV}$. The injector temperature was $250{ }^{\circ} \mathrm{C}$, and the ion-source temperature was $250{ }^{\circ} \mathrm{C}$. The FID temperature was set to $250^{\circ} \mathrm{C}$, and the gas supplies for the FID were hydrogen, air, and helium at flow rates of 30,300 , and $30 \mathrm{~mL} / \mathrm{min}$, respectively. Quantification of each compound was estimated by FID peak-area normalization (\%). Compound concentrations were calculated from the GC peak areas and arranged in order of GC elution.

Identification of individual compounds of the essential oil was performed by computerized matching of the acquired mass spectra with those stored in NIST21, NIST107 and WILEY8 mass spectral library of the GC-MS data system. A mixture of hydrocarbons $\left(\mathrm{C}_{9} \mathrm{H}_{20}-\mathrm{C}_{19} \mathrm{H}_{40}\right)$ was injected under these same conditions, and compounds were identified by comparing the obtained spectra with those of the equipment data bank and by the Kovats index, calculated for each compound, as previously described (ADAMS, 2007). Retention indices were obtained with the equation proposed by Van den dool and Kratz (1963).

Pure monosporic cultures of the fungi $L$. theobromae (LT), F. pallidoroseum (FP), and $F$. solani (FS), obtained from the Laboratory of Phytopathology of UFS, were used in the experiment, which consisted of a completely randomized design with three replications. Essential oils, carvone enantiomers (Sigma-Aldrich), and citral (Sigma-Aldrich) were solubilized in $1 \%$ DMSO and homogenized in PDA medium (Potato Dextrose Agar, HIMEDIA). Concentrations of 0.01; $0.05 ; 0.1 ; 0.2 ; 0.3 ; 0.5$ and $1.0 \mathrm{~mL} / 100 \mathrm{~mL}$ were tested for each fungus. The experiment was conducted as described by Sampaio et al. (2016).

Afterward, solutions were poured into 9.0 $\mathrm{cm}$ diameter Petri dishes, which were inoculated in the center with a $7 \mathrm{~mm}$ diameter culture medium disk containing mycelia of the fungus culture. Petri dishes were sealed, identified, and incubated in a B.O.D chamber at $22 \pm 3{ }^{\circ} \mathrm{C}$, with a 12-hour photoperiod. The mycelial diameter was measured (mean of two diametrically opposed measurements) using a pachymeter, at $96 \mathrm{~h}$ after the beginning of incubation. Petri dishes without essential oil but containing PDA medium plus 1\% DMSO solvent, and Petri dishes containing only PDA medium were used as controls. Viper $700(0.07 \% \mathrm{w} / \mathrm{v})$, a broadspectrum fungicide, was used as the positive control. At the end of the evaluations, the percentage of mycelial growth inhibition (MGI) of the treatments in relation to the control containing PDA was calculated using the formula: $\mathrm{MGI}=($ diameter of the PDA control - diameter of the treatment)/diameter of the PDA control) $\times 100$.

To evaluate whether essential oils, carvone enantiomers, and citral had a fungistatic or fungicidal profile, the discs containing mycelium of the treatments without visible growth were transferred to new Petri dishes containing only the PDA culture medium. These Petri dishes were incubated for another $96 \mathrm{~h}$. Afterward, concentrations that showed no mycelial growth were considered as fungicidal concentrations. Conversely, the concentrations that presented mycelial growth were considered as fungistatic concentrations. The lowest concentration at which no mycelial growth was observed, but which presented mycelium growth after the transfer to the PDA medium without essential oil or without the compounds was considered as the Minimal Inhibitory Concentration (MIC). The lowest concentration at which no mycelial growth was observed, even after the transfer to PDA medium, was considered as the Minimal Fungicidal Concentration (MFC).

Mycelial growth inhibition data were expressed as the mean \pm standard error of the mean, obtained using the Graph Pad Prism ${ }^{\circledR}$ software.

\section{RESULTS AND DISCUSSION}

The citral chemotype (geranial + neral) had geranial as its major compound (46.25\% for LA-10; $44.17 \%$ for LA-44; and $38.63 \%$ for LA-29), followed by the neral $(33.50 \%$ for LA-10; $31.13 \%$ for LA-44; and $25.12 \%$ for LA-29), i.e., the percentage of citral detected in these accessions was of $79.75 \%$ for LA-10; $75.30 \%$ for LA-44; and $63.75 \%$ for LA-29. The carvone chemotype presented carvone as its major compound $(52.94 \%$ for LA-13; and $63.47 \%$ for LA-57) (Table 2). 
Table 2. Chemical composition of the essential oils of five Lippia alba accessions

\begin{tabular}{|c|c|c|c|c|c|c|}
\hline \multirow{2}{*}{ Compound } & \multirow{2}{*}{$\mathrm{RRI}^{1}$} & \multicolumn{5}{|c|}{ L. $a l b a^{2}$ accessions } \\
\hline & & LA-13 & LA-57 & LA-10 & LA-29 & LA-44 \\
\hline Sabinene & 969 & $2.27 \pm 0.01$ & $0.03 \pm 0.03$ & - & $0.83 \pm 0.01$ & $0.27 \pm 0.01$ \\
\hline Myrcene & 988 & $0.61 \pm 0.01$ & $0.49 \pm 0.02$ & $1.25 \pm 0.03$ & $4.97 \pm 0.05$ & $2.63 \pm 0.03$ \\
\hline Limonene & 1024 & $26.95 \pm 0.16$ & $25.86 \pm 0.47$ & - & $1.56 \pm 0.02$ & $0.54 \pm 0.01$ \\
\hline Linalool & 1095 & $1.73 \pm 0.02$ & $0.87 \pm 0.04$ & $0.95 \pm 0.01$ & $1.76 \pm 0.04$ & $0.74 \pm 0.03$ \\
\hline Neral & 1235 & - & - & $33.50 \pm 0.19$ & $25.12 \pm 0.12$ & $31.13 \pm 0.19$ \\
\hline Carvone & 1239 & $52.94 \pm 0.17$ & $63.47 \pm 0.43$ & - & $3.65 \pm 0.04$ & $0.35 \pm 0.35$ \\
\hline Geranial & 1264 & - & - & $46.25 \pm 0.53$ & $38.63 \pm 0.74$ & $44.17 \pm 0.84$ \\
\hline$\beta$-elemene & 1389 & - & $0.11 \pm 0.11$ & $0.85 \pm 0.01$ & $3.88 \pm 0.11$ & - \\
\hline$\beta$-caryophyllene & 1417 & - & $0.33 \pm 0.02$ & $2.42 \pm 0.04$ & $3.51 \pm 0.06$ & $2.36 \pm 0.04$ \\
\hline$\gamma$-muurolene & 1478 & $2.54 \pm 0.07$ & $2.25 \pm 0.07$ & $0.60 \pm 0.01$ & $4.09 \pm 0.05$ & - \\
\hline Elemol & 1548 & $4.33 \pm 0.10$ & - & - & - & - \\
\hline Caryophyllene oxide & 1582 & - & - & $7.28 \pm 0.13$ & $2.35 \pm 0.07$ & $8.06 \pm 0.25$ \\
\hline
\end{tabular}

${ }^{1}$ Relative retention index; ${ }^{2}$ Mean values $( \pm$ SEM). Traces indicate that compound was not found.

For all the fungi studied, after $96 \mathrm{~h}$ of incubation, the positive control - broad spectrum fungicide Viper 700 - at the recommended concentration of $0.07 \%$ provided complete mycelial growth inhibition, proving its efficacy in the control of these phytopathogens.

From the concentration of $0.2 \mathrm{~m} \beta \mathrm{L} / 100 \mathrm{~mL}$, all the accessions and carvone enantiomers were effective against the fungus LT, except the LA-44 accession, for which the maximum inhibition occurred from the concentration of $0.3 \mathrm{~mL} / 100 \mathrm{~mL}$. Citral was the most effective against LT, with $100 \%$ of MGI from the concentration of $0.05 \mathrm{~mL} / 100 \mathrm{~mL}$, (Table 3). This difference in the ability of accession LA-44 to inhibit the mycelial growth of LT at a higher concentration, in relation to the other accessions of the same chemotype, may be due to the chemical composition of the essential oil, which contains $75.30 \%$ of citral (general + geranial), but does not present the compounds $\beta$-elemene and $\gamma$ muurolene, unlike the accessions LA-10 and LA-29 (Table 2). The major compounds are known to be the main responsible for the biological properties of essential oils; however, the presence of other compounds at lower concentrations can both potentiate the antifungal effect or reduce its toxicity through synergistic or antagonistic effects, respectively. (BASSOLÉ; JULIANI, 2012).

All accessions and enantiomers caused $100 \%$ of MGI against FP fungus from the concentration of $0.2 \mathrm{~mL} / 100 \mathrm{~mL}$. Once again, citral stood out by providing the same result as the other treatments from the concentration of $0.1 \mathrm{~mL} / 100$ $\mathrm{mL}$. However, unlike what happened to LT, all accessions, enantiomers, and citral inhibited the FP even at low concentrations (Table 3 ).

Regarding the fungus FS, the carvone enantiomers and citral caused $100 \%$ of MGI from the concentration of $0.1 \mathrm{~mL} / 100 \mathrm{~mL}$ while all accessions caused $100 \%$ of MGI from the concentration of $0.2 \mathrm{~mL} / 100 \mathrm{~mL}$. Similar to what occurred to FP, all treatments inhibited FS even at lower concentrations (Table 3).

Citral and carvone enantiomers presented the lowest MIC values $(0.1 \mathrm{~mL} / 100 \mathrm{~mL})$ for the FS fungus. The MIC of citral for LT and FP were not determined at the concentrations tested. $(R)-(-)$ carvone enantiomer presented the lowest MIC $(0.1$ $\mathrm{mL} / 100 \mathrm{~mL}$ ) for the LT fungus. Most of the other accessions presented MIC of $0.2 \mathrm{~mL} / 100 \mathrm{~mL}$ for the three fungi (Table 4).

Regarding the minimum fungicidal concentration (MFC), citral stood out and equated to the viper 700 fungicide, with MFC values from 0.05 $\mathrm{mL} / 100 \mathrm{~mL}$ (LT). Citral and carvone presented the same MFC for FS $(0.2 \mathrm{~mL} / 100 \mathrm{~mL})$. The other accessions showed MFC values from $0.3 \mathrm{~mL} / 100$ $\mathrm{mL}$ for the three fungi (Table 4).

The lowest MIC and MFC values obtained for all the essential oils, and especially for citral and carvone enantiomers proved the fungitoxic potential of $L$. alba against LT, FP, and FS. Essential oils and their compounds may act as fungistatic and/or fungicidal agents, depending on the concentrations used, as observed in this work. The same essential oil may be an active agent against a broad spectrum of microorganism species; however, the minimum inhibitory concentrations may vary (ANTUNES; CAVACO, 2010). 
Table 3. Percentage of mycelial growth inhibition [(MGI) (mean \pm standard error of the mean)] of the fungi $L$. theobromae (LT), $F$. pallidoroseum (FP), and $F$. solani (FS) in function of the concentrations of essential oil of $L$. alba genotypes and major compounds.

\begin{tabular}{|c|c|c|c|c|c|c|c|c|}
\hline $\begin{array}{l}\text { Concentratio } \\
\mathrm{n} \quad(\mathrm{mL} / 100 \\
\mathrm{mL})\end{array}$ & LA-13 & LA-57 & $\begin{array}{l}(R)-(-) \\
\text { Carvone }\end{array}$ & $\begin{array}{l}(S)-(+) \\
\text { Carvone }\end{array}$ & LA-10 & LA-29 & LA-44 & Citral \\
\hline \multicolumn{9}{|c|}{ MGI Lasiodiplodia theobromae (LT) } \\
\hline 1.0 & $\begin{array}{l}100.0 \pm 0 . \\
0\end{array}$ & $100.0 \pm 0.0$ & $100.0 \pm 0.0$ & $\begin{array}{l}100.0 \pm 0 \\
.0\end{array}$ & $\begin{array}{l}100.0 \pm 0 \\
.0\end{array}$ & $\begin{array}{l}100.0 \pm 0 \\
.0\end{array}$ & $\begin{array}{l}100.0 \pm 0 \\
.0\end{array}$ & $\begin{array}{l}100.0 \pm 0 . \\
0\end{array}$ \\
\hline 0.5 & $\begin{array}{l}100.0 \pm 0 . \\
0\end{array}$ & $100.0 \pm 0.0$ & $100.0 \pm 0.0$ & $\begin{array}{l}100.0 \pm 0 \\
.0\end{array}$ & $\begin{array}{l}100.0 \pm 0 \\
.0\end{array}$ & $\begin{array}{l}100.0 \pm 0 \\
.0\end{array}$ & $\begin{array}{l}100.0 \pm 0 \\
.0\end{array}$ & $\begin{array}{l}100.0 \pm 0 . \\
0\end{array}$ \\
\hline 0.3 & $\begin{array}{l}100.0 \pm 0 . \\
0\end{array}$ & $100.0 \pm 0.0$ & $100.0 \pm 0.0$ & $\begin{array}{l}100.0 \pm 0 \\
.0\end{array}$ & $\begin{array}{l}100.0 \pm 0 \\
.0\end{array}$ & $\begin{array}{l}100.0 \pm 0 \\
.0\end{array}$ & $\begin{array}{l}100.0 \pm 0 \\
.0\end{array}$ & $\begin{array}{l}100.0 \pm 0 . \\
0\end{array}$ \\
\hline 0.2 & $\begin{array}{l}100.0 \pm 0 . \\
0\end{array}$ & $100.0 \pm 0.0$ & $100.0 \pm 0.0$ & $\begin{array}{l}100.0 \pm 0 \\
.0\end{array}$ & $\begin{array}{l}100.0 \pm 0 \\
.0\end{array}$ & $\begin{array}{l}100.0 \pm 0 \\
.0\end{array}$ & $0.0 \pm 0.0$ & $\begin{array}{l}100.0 \pm 0 \\
0\end{array}$ \\
\hline 0.1 & $0.0 \pm 0.0$ & $41.5 \pm 1.8$ & $0.0 \pm 0.0$ & $\begin{array}{l}84.8 \pm 0 \\
5\end{array}$ & $0.0 \pm 0.0$ & $0.0 \pm 0.0$ & $0.0 \pm 0.0$ & $\begin{array}{l}100.0 \pm 0 \\
0\end{array}$ \\
\hline 0.05 & $0.0 \pm 0.0$ & $11.29 \pm 0.5$ & $0.0 \pm 0.0$ & $0.0 \pm 0.0$ & $0.0 \pm 0.0$ & $0.0 \pm 0.0$ & $0.0 \pm 0.0$ & $\begin{array}{l}100.0 \pm 0 . \\
0\end{array}$ \\
\hline 0.01 & $0.0 \pm 0.0$ & $0.0 \pm 0.0$ & $0.0 \pm 0.0$ & $0.0 \pm 0.0$ & $0.0 \pm 0.0$ & $0.0 \pm 0.0$ & $0.0 \pm 0.0$ & $0.0 \pm 0.0$ \\
\hline \multicolumn{9}{|c|}{ MGI Fusarium pallidoroseum (FP) } \\
\hline 1.0 & $\begin{array}{l}100.0 \pm 0 . \\
0\end{array}$ & $100.0 \pm 0.0$ & $100.0 \pm 0.0$ & $\begin{array}{l}100.0 \pm 0 \\
.0\end{array}$ & $\begin{array}{l}100.0 \pm 0 \\
.0\end{array}$ & $\begin{array}{l}100.0 \pm 0 \\
.0\end{array}$ & $\begin{array}{l}100.0 \pm 0 \\
.0\end{array}$ & $\begin{array}{l}100.0 \pm 0 . \\
0\end{array}$ \\
\hline 0.5 & $\begin{array}{l}100.0 \pm 0 . \\
0\end{array}$ & $100.0 \pm 0.0$ & $100.0 \pm 0.0$ & $\begin{array}{l}100.0 \pm 0 \\
.0\end{array}$ & $\begin{array}{l}100.0 \pm 0 \\
.0\end{array}$ & $\begin{array}{l}100.0 \pm 0 \\
.0\end{array}$ & $\begin{array}{l}100.0 \pm 0 \\
.0\end{array}$ & $\begin{array}{l}100.0 \pm 0 . \\
0\end{array}$ \\
\hline 0.3 & $\begin{array}{l}100.0 \pm 0 . \\
0\end{array}$ & $100.0 \pm 0.0$ & $100.0 \pm 0.0$ & $\begin{array}{l}100.0 \pm 0 \\
.0\end{array}$ & $\begin{array}{l}100.0 \pm 0 \\
.0\end{array}$ & $\begin{array}{l}100.0 \pm 0 \\
.0\end{array}$ & $\begin{array}{l}100.0 \pm 0 \\
.0\end{array}$ & $\begin{array}{l}100.0 \pm 0 . \\
0\end{array}$ \\
\hline 0.2 & $\begin{array}{l}100.0 \pm 0 . \\
0\end{array}$ & $100.0 \pm 0.0$ & $100.0 \pm 0.0$ & $\begin{array}{l}100.0 \pm 0 \\
.0\end{array}$ & $\begin{array}{l}100.0 \pm 0 \\
.0\end{array}$ & $\begin{array}{l}100.0 \pm 0 \\
.0\end{array}$ & $\begin{array}{l}100.0 \pm 0 \\
.0\end{array}$ & $\begin{array}{l}100.0 \pm 0 . \\
0\end{array}$ \\
\hline 0.1 & $57.2 \pm 0.4$ & $59.1 \pm 3.0$ & $76.2 \pm 1.5$ & $\begin{array}{l}73.9 \pm 7 \\
7\end{array}$ & $\begin{array}{l}87.1 \pm 0 \\
5\end{array}$ & $\begin{array}{l}51.4 \pm 0 . \\
8\end{array}$ & $\begin{array}{l}57.6 \pm 1 \\
1\end{array}$ & $\begin{array}{l}100.0 \pm 0 . \\
0\end{array}$ \\
\hline 0.05 & $45.0 \pm 1.6$ & $38.9 \pm 1.3$ & $54.0 \pm 1.2$ & $\begin{array}{l}65.6 \pm 1 \\
8\end{array}$ & $\begin{array}{l}57.2 \pm 0 \\
7\end{array}$ & $\begin{array}{l}40.5 \pm 0 \\
6\end{array}$ & $\begin{array}{l}42.7 \pm 1 \\
5\end{array}$ & $70.1 \pm 0.9$ \\
\hline 0.01 & $30.2 \pm 1.0$ & $25.4 \pm 0.4$ & $39.5 \pm 2.9$ & $\begin{array}{l}43.4 \pm 0 \\
7\end{array}$ & $\begin{array}{l}39.5 \pm 0 . \\
7\end{array}$ & $\begin{array}{l}23.7 \pm 1 \\
9\end{array}$ & $\begin{array}{l}23.4 \pm 2 . \\
0\end{array}$ & $43.7 \pm 1.3$ \\
\hline MGI Fusar & um solani & FS) & & & & & & \\
\hline 1.0 & $\begin{array}{l}100.0 \pm 0 . \\
0\end{array}$ & $100.0 \pm 0.0$ & $100.0 \pm 0.0$ & $\begin{array}{l}100.0 \pm 0 \\
.0\end{array}$ & $\begin{array}{l}100.0 \pm 0 \\
.0\end{array}$ & $\begin{array}{l}100.0 \pm 0 \\
.0\end{array}$ & $\begin{array}{l}100.0 \pm 0 \\
.0\end{array}$ & $\begin{array}{l}100.0 \pm 0 . \\
0\end{array}$ \\
\hline 0.5 & $\begin{array}{l}100.0 \pm 0 . \\
0\end{array}$ & $100.0 \pm 0.0$ & $100.0 \pm 0.0$ & $\begin{array}{l}100.0 \pm 0 \\
.0\end{array}$ & $\begin{array}{l}100.0 \pm 0 \\
.0\end{array}$ & $\begin{array}{l}100.0 \pm 0 \\
.0\end{array}$ & $\begin{array}{l}100.0 \pm 0 \\
.0\end{array}$ & $\begin{array}{l}100.0 \pm 0 . \\
0\end{array}$ \\
\hline 0.3 & $\begin{array}{l}100.0 \pm 0 . \\
0\end{array}$ & $100.0 \pm 0.0$ & $100.0 \pm 0.0$ & $\begin{array}{l}100.0 \pm 0 \\
.0\end{array}$ & $\begin{array}{l}100.0 \pm 0 \\
.0\end{array}$ & $\begin{array}{l}100.0 \pm 0 \\
.0\end{array}$ & $\begin{array}{l}100.0 \pm 0 \\
.0\end{array}$ & $\begin{array}{l}100.0 \pm 0 . \\
0\end{array}$ \\
\hline 0.2 & $\begin{array}{l}100.0 \pm 0 . \\
0\end{array}$ & $100.0 \pm 0.0$ & $100.0 \pm 0.0$ & $\begin{array}{l}100.0 \pm 0 \\
.0\end{array}$ & $\begin{array}{l}100.0 \pm 0 \\
.0\end{array}$ & $\begin{array}{l}100.0 \pm 0 \\
.0\end{array}$ & $\begin{array}{l}100.0 \pm 0 \\
.0\end{array}$ & $\begin{array}{l}100.0 \pm 0 . \\
0\end{array}$ \\
\hline 0.1 & $36.5 \pm 0.7$ & $75.7 \pm 0.4$ & $100.0 \pm 0.0$ & $\begin{array}{l}100.0 \pm 0 \\
.0\end{array}$ & $\begin{array}{l}43.6 \pm 0 . \\
7\end{array}$ & $\begin{array}{l}66.5 \pm 0 \\
8\end{array}$ & $\begin{array}{l}54.7 \pm 1 \\
1\end{array}$ & $\begin{array}{l}100.0 \pm 0 . \\
0\end{array}$ \\
\hline 0.05 & $22.9 \pm 0.2$ & $59.1 \pm 1.2$ & $57.5 \pm 1.1$ & $\begin{array}{l}79.6 \pm 0 . \\
5\end{array}$ & $\begin{array}{l}32.4 \pm 1 \\
3\end{array}$ & $\begin{array}{l}43.8 \pm 0 \\
7\end{array}$ & $\begin{array}{l}30.2 \pm 1 \\
0\end{array}$ & $77.9 \pm 0.6$ \\
\hline 0.01 & $13.6 \pm 0.9$ & $40.0 \pm 1.3$ & $43.6 \pm 1.0$ & $\begin{array}{l}50.1 \pm 0 . \\
4\end{array}$ & $\begin{array}{l}18.8 \pm 0 \\
3\end{array}$ & $\begin{array}{l}27.8 \pm 0 . \\
6\end{array}$ & $\begin{array}{l}19.3 \pm 1 \\
3\end{array}$ & $28.0 \pm 1.2$ \\
\hline
\end{tabular}


Table 4. Minimum Inhibitory Concentration (MIC) and Minimum Fungicidal Concentration (MFC) of essential oils of Lippia alba accessions, carvone enantiomers, and citral for the phytopathogenic fungi $L$. theobromae (LT), F. pallidoroseum (FP), and F. solani (FS).

\begin{tabular}{|c|c|c|c|c|c|c|}
\hline \multirow[t]{2}{*}{ Accession/compound } & \multicolumn{3}{|c|}{$\begin{array}{l}\text { Minimum Inhibitory } \\
\text { Concentration (MIC mL/100 mL) }\end{array}$} & \multicolumn{2}{|c|}{$\begin{array}{l}\text { Minimum Fungicidal } \\
\text { (MFC } \mathrm{mL} / 100 \mathrm{~mL})\end{array}$} & \multirow{2}{*}{$\begin{array}{c}\text { Concentration } \\
\text { FS } \\
\end{array}$} \\
\hline & LT & FP & FS & LT & FP & \\
\hline LA-13 & 0.2 & 0.2 & 0.2 & 0.3 & 0.3 & 0.3 \\
\hline LA-57 & 0.2 & 0.2 & 0.2 & 0.3 & 0.3 & 0.3 \\
\hline$(R)$-(-)-carvone & 0.1 & 0.2 & 0.1 & 0.2 & 0.3 & 0.2 \\
\hline$(S)-(+)$-carvone & 0.2 & 0.2 & 0.1 & 0.3 & 0.3 & 0.2 \\
\hline LA-10 & 0.2 & 0.2 & 0.2 & 0.3 & 0.3 & 0.3 \\
\hline LA-29 & 0.2 & 0.2 & 0.2 & 0.5 & 0.3 & 0.3 \\
\hline LA-44 & 0.3 & 0.2 & 0.2 & 0.5 & 0.3 & 0.3 \\
\hline Citral & nd & nd & 0.1 & 0.05 & 0.1 & 0.2 \\
\hline
\end{tabular}

nd: not determined at the concentrations tested.

The outstanding fungicidal activity of citral (mainly against LT, in this work), has been discussed by several authors, who relate its fungicidal activity to the high capacity of receiving electrons from the fungus cell by a charge transfer with one electron donor present in the cell, resulting in the fungus death (KURITA et al., 1981). Another probable mode of action of citral is related to the cell wall synthesis or ergosterol (LIMA et al., 2012). Guimarães et al. (2011) reported similar results on the inhibition power of citral by investigating the fungitoxic effects of the essential oil of lemongrass and its major compound (citral) on the phytopathogens Fusarium oxysporum cubense, Colletotrichum gloeosporioides, Bipolaris sp., and Alternaria alternata. The authors reported that citral caused high mycelial inhibitions to all phytopathogens. Shukla et al., (2009), using the essential oil of $L$. alba and its major compounds geranial and neral (citral) - observed $100 \%$ and 79.4\% MGI in A. alternata for neral and geranial, respectively; and 82.8 and $96.6 \%$ MGI in $F$. oxysporum for the same compounds, respectively. Garcia et al. (2008) tested the monoterpenes citral, citronellal, L-carvone, isopulegol, and $\alpha$-pinene on the fungi $C$. musae, C. gloeosporioides, and $F$. subglutinans $\mathrm{f}$. sp ananás, and reported citral as the most effective, with potent fungicidal activity at concentrations higher than $0.5 \%$.

For all the fungi, the accessions representative of the citral chemotype reached maximum values of MGI at higher concentrations when compared with the pure citral. This result can be explained for the essential oils of accessions LA10, LA-44, and LA-29 are constituted by a series of other compounds that do not act in the same way as citral against mycelial growth inhibition, despite containing high concentrations of citral (geranial + neral). In fact, the compounds present at lower concentrations may act to reduce the toxicity of the major compound to fungi. In addition, pure citral was used at a higher concentration than that present in the essential oil, and thus no other compound acted to promote fungal survival.

In relation to the fungus LT, the highest mycelial growth inhibition promoted by the accession LA-57 $(41.48 \%$ for the concentration of $0.1 \mathrm{~mL} / 100 \mathrm{~mL}$ ) in relation to LA-13 and the other accessions (which did not present mycelial growth inhibition for this fungus at this concentration) can be explained by the higher percentage of carvone of its chemical composition (63.47\%). Both carvone enantiomers also presented considerable inhibition activity and thus confirmed the antimicrobial activity of carvone, which had already been reported in other studies (AGGARWAL et al., 2002; CARVALHO; FONSECA, 2006; MA et al., 2015; MORO et al., 2017).

The action of the essential oils on fungi is related to the toxic effects on their cell walls - which is mostly formed by chitin - making them permeable, and thus causing leakage of cellular contents (PIPER et al., 2001; AMARAL; BARA, 2005; OLIVEIRA et al., 2011; SILVA et al., 2014). Rasooli et al., (2006) verified by transmission electron microscopy that the essential oil of the species Thymus eriocalyx promoted severe damage to cell walls, membranes, and organelles of the fungus Aspergillus niger. Such effect on fungal cell walls may be associated with the lipid oxidation of the cell membrane induced by some of the essential oil compounds (MONTANARI et al., 2012). The importance of the hydrophobicity of essential oils and their compounds is also emphasized since they can interact with the lipid layer of cell membranes, changing their structures, making them less selective, leading to the extravasation of ions and other cell constituents (KUMAR et al., 2008). 
Despite presenting higher MFC values for LT and FS when compared with isolated compounds (carvone and citral), L. alba accessions were also effective against fungi tested. Using essential oil to obtain natural fungicides is more advisable than using isolated compounds. According to Carson et al. (2002), essential oils appear to have no specific cellular targets due to its large number of compounds. Such fact can hinder the emergence of fungal resistance against the fungicides developed from essential oils.
Essential oils of L. alba accessions, carvone enantiomers, and citral have great potential to control phytopathogenic fungi and can be considered as an alternative to fungicides for presenting inhibitory and fungicidal effect on these organisms at low concentrations.

\section{ACKNOWLEDGMENTS}

The authors thank CNPq, FAPITEC/SE, CAPES, FINEP, and RENORBIO for their financial support for this work.

RESUMO: O objetivo do trabalho foi avaliar a atividade antifúngica in vitro de óleos essenciais de Lippia alba pertencentes ao quimiotipo carvona (LA-13 e LA-57) e ao quimiotipo citral (LA-10, LA-29 e LA-44); dos enantiômeros da carvona: $(R)-(-)$-carvona e $(S)-(+)$-carvona; e do citral sobre os fungos fitopatogênicos Lasiodiplodia theobromae (LT), Fusarium pallidoroseum (FP) e Fusarium solani (FS). Foram testadas as concentrações 0,$01 ; 0,05 ; 0,1 ; 0,2 ; 0,3 ; 0,5$ e 1,0 $\mathrm{mL} / 100 \mathrm{~mL}$, e, após 96h de incubação, a porcentagem de inibição do crescimento micelial (ICM) foi calculada em relação ao controle. Foram determinadas as Concentrações Inibitórias Mínimas (CIM) e Fungicidas Mínimas (CFM) para os óleos essenciais e compostos. A partir da concentração de $0,2 \mathrm{~mL} / 100 \mathrm{~mL}$ todos os acessos e os enantiômeros da carvona foram efetivos contra LT, exceto o acesso LA-44, que proporcionou máxima inibição a partir da concentração de $0,3 \mathrm{~mL} / 100 \mathrm{~mL}$. O monoterpeno citral foi o mais efetivo contra LT, pois a partir da concentração de $0,05 \mathrm{~mL} / 100 \mathrm{~mL}, 100 \%$ de ICM foi observada. Todos os acessos e enantiômeros da carvona causaram 100\% de ICM contra o fungo FP, a partir da concentração de $0,2 \mathrm{~mL} / 100 \mathrm{~mL}$. Novamente, o composto citral de destacou por causar máxima ICM a partir da concentração de $0,1 \mathrm{~mL} / 100 \mathrm{~mL}$. Contra o fungo FS, os enantiômeros da carvona e o citral causaram $100 \%$ de ICM a partir da concentração de $0,1 \mathrm{~mL} / 100 \mathrm{~mL}$, enquanto os acessos proporcionaram mesmos resultados a partir da concentração de $0,2 \mathrm{~mL} / 100 \mathrm{~mL}$. O citral e os enantiômeros da carvona apresentaram os menores valores de CIM $(0,1$ $\mathrm{mL} / 100 \mathrm{~mL}$ ) frente ao FS. Não foi possível determinar a CIM do citral para LT e FP nas concentrações testadas. O enantiômero $(R)-(-)$-carvone apresentou a menor CIM $(0,1 \mathrm{~mL} / 100 \mathrm{~mL})$ para o fungo LT. Os acessos apresentaram CIM a partir de 0,2

$\mathrm{mL} / 100 \mathrm{~mL}$ para os três fungos. Em relação à concentração fungicida mínima (CFM), o citral se destacou com a menor CFM $(0,05 \mathrm{~mL} / 100 \mathrm{~mL})$ para LT. Citral e carvonas apresentaram a mesma CFM para FS $(0,2 \mathrm{~mL} / 100 \mathrm{~mL})$. Os acessos apresentaram CFM a partir de $0,3 \mathrm{~mL} / 100 \mathrm{~mL}$ para os três fungos. Os óleos essenciais dos acessos de $L$. alba, e os monoterpenos carvona e o citral foram eficientes no controle dos fungos fitopatogênicos e são considerados como uma alternativa em relação aos fungicidas sintéticos por apresentarem efeitos inibitórios e fungicidas contra esses microorganismos quando utilizados em baixas concentrações.

PALAVRAS-CHAVE: Erva-cidreira-brasileira. Compostos majoritários. Lasiodiplodia theobromae. Fusarium pallidoroseum. Fusarium solani.

\section{REFERENCES}

ADAMS, R. P. Identification of essential oil components by gas chromatography/mass spectroscopy. 4th ed., Allured: Carol Stream, 2007. 804p.

AGGARWAL, K. K.; KHANUJA, S. P. S.; AHMAD, A.; KUMAR, T. R. S.; GUPTA, V. K.; KUMAR, S. Antimicrobial activity profiles of the two enantiomers of limonene and carvone isolated from the oils of Mentha spicata and Anethum sowa. Flavour Frag. J., v. 17, n. 1, p. 59-63, jan. 2002. https://doi.org/10.1002/ffj.1040

AL-SADI, A. M.; AL-GHAITHI, A. G.; AL-FAHDI, N.; AL-YAHYAI, R. A. Characterization and pathogenicity of fungal pathogens associated with root diseases of citrus in Oman. Int. J. Agric. Biol., v. 16, n. 2, p. 371-376, 2014. Disponível em http://www.fspublishers.org/published_papers/94276_..pdf 
AL-SADI, A. M.; AL-MASOODI, R. S.; AL-ISMAILI, M.; AL-MAHMOOLI, I. H. Population structure and development of resistance to hymexazol among Fusarium solani populations from date palm, citrus and cucumber. J. Phytopathol., v. 163, p. 947-955, mar. 2015. https://doi.org/10.1111/jph.12397

AMARAL, M. F. Z. J.; BARA, M. T. F. Avaliação da atividade antifúngica de extratos de plantas sobre o crescimento de fitopatógenos. Braz. J. Pharm. Sci., v. 2, n. 2, p. 5-8, 2005. https://doi.org/10.1002/ffj.1986

ANTUNES, M. D. C.; CAVACO, A. The use of essential oils for postharvest decay control. A review. Flavour Frag. J., v. 25, n. 5, p. 351-366, sept. 2010. https://doi.org/10.1002/ffj.1986

BASSOLÉ, I. H. N.; JULIANI, H. R. Essential oils in combination and their antimicrobial properties. Molecules, v. 17, n. 4, p. 3989-4006, apr. 2012. https://doi.org/10.3390/molecules17043989

BASSOLÉ, I. H. N.; H. RODOLFO JULIANI, H. R. Essential oils in combination and their antimicrobial properties. Molecules, v. 17, p. 3989-4006, apr. 2012. https://doi.org/10.3390/molecules17043989

BERTSCH, C.; RAMÍREZ-SUERO, M.; MAGNIN-ROBERT, M.; LARIGNON, P.; CHONG, J.; ABOUMANSOUR, E.; SPAGNOLO, A.; CLÉMENT, C.; FONTAINE, F. Grapevine trunk diseases: complex and still poorly understood - Review. Plant Pathol., v. 62, n. 2, p. 243-265, apr. 2013.

https://doi.org/10.1111/j.1365-3059.2012.02674.x

BLANK, A. F.; CAMÊLO, L. C. A.; ARRIGONI-BLANK, M. F.; PINHEIRO, J. B.; ANDRADE, T. M.; NICULAU, E. S.; ALVES, P. B. Chemical diversity in Lippia alba (Mill.) N.E. Brown germplasm. Sci. World J., v. 2015, p. 1-11, 2015. http://dx.doi.org/10.1155/2015/321924

BRITO, T. I.; MOMENTÉ, V. G.; NASCIMENTO, I. R. Lippia alba: estudos químicos, etnofarmacológicos e agronômicos. Appl. Res. \& Agrotec., Guarapuvava, v. 4, n. 1, p. 204-220, 2011. DOI: http://dx.doi.org/10.5777/PAeT.V4.N1.12

CARSON, C. F.; MEE, B. J.; RILEY, T. V. Mechanism of action of Melaleuca alternifolia (tea tree) oil on Staphylococcus aureus determined by time-kill, lysis, leakage and salt tolerance assays and electron microscopy. Antimicrob. Agents Chemother., v. 46, n. 6, p. 1914-1920, june. 2002. http://dx.doi.org/10.1128/AAC.46.6.1914-1920.2002

CARVALHO, C. C. R.; FONSECA, M. M. R. Carvone: why and how should one bother to produce this terpene. Food Chem., v. 95, n. 3, p. 413-422, apr. 2006.

https://doi.org/10.1016/j.foodchem.2005.01.003

CIPRIANO, A. K. A. L.; GONDIM, D. M. F.; VASCONCELOS, I. M.; MARTINS, J. A. M.; MOURA, A. A.; MORENO, F. B.; MONTEIRO-MOREIRA, A. C. O.; MELO, J. G. M.; CARDOSO, J. E.; PAIVA, A. L. S.; OLIVEIRA, J. T. A. Proteomic analysis of responsive stem proteins of resistant and susceptible cashew plants after Lasiodiplodia theobromae infection. J. Proteomics, v. 113, n. 15, p. 90-109, feb. 2015. https://doi.org/10.1016/j.jprot.2014.09.022

DINIZ, S. P. S. S.; COELHO, J. S.; ROSA, G. S.; SPECIAN, V.; OLIVEIRA, R. C.; OLIVEIRA, R. R. Bioatividade do óleo essencial de Mentha arvensis L. no controle de fungos fitopatógenos. Rev. Bras. Plantas Med., Botucatu, v. 10, n. 4, p. 9-11, june. 2008.

EHLERT, P. A. D.; BLANK, A. F.; ARRIGONI-BLANK, M. F.; PAULA, J. W. A.; CAMPOS, D. A.; ALVIANO, C. S. Tempo de hidrodestilação na extração de óleo essencial de sete espécies de plantas medicinais. Rev. Bras. Plantas Med., Botucatu, v. 8, n. 2, p. 79-80, 2006. 
FERNANDES-NETO, M. L.; SARCINELLI, P. N. Agrotóxicos em água para consumo humano: uma abordagem de avaliação de risco e contribuição ao processo de atualização da legislação brasileira. Eng. Sanit. Ambient., Rio de Janeiro, v. 14, n. 1, p. 69-78, jan. 2009.

http://dx.doi.org/10.1590/S1413-41522009000100008

FREIRE, F. C. O.; CARDOSO, J. E.; VIANA, F. M. P.; MARTINS, M. V. V. Status of Lasiodiplodia theobromae as a plant pathogen in Brazil. Essentia, Sobral, v. 12, n. 2, p. 53-71, 2011.

GARCIA, R.; ALVES, E. S. S.; SANTOS, M. P.; AQUIJE, G. M. F. V.; FERNANDES, A. A. R.; SANTOS, R. B.; VENTURA, J. A.; FERNANDE, P. M. B. Antimicrobial Activity and Potential Use of Monoterpenes as Tropical Fruits Preservatives. Braz. J. Microbiol., São Paulo, v. 39, n. 1, p.163-168, jan. 2008.

GUIMARÃES, L. G. L.; CARDOSO, M. G.; SOUSA, P. E.; ANDRADE, J.; VIEIRA, S. S. Atividades antioxidante e fungitóxica do óleo essencial de capim-limão e do citral. Rev. Ciênc. Agron., Fortaleza, v. 42, n. 2, p. 464-472, apr. 2011. http://dx.doi.org/10.1590/S1806-66902011000200028

HENNEBELLE, T.; SAHPAZ, S.; JOSEPH, H.; BAILLEUL, F. Ethnopharmacology of Lippia alba. J. Ethnopharmacol., v. 116, n. 2, p. 211-222, mar. 2008. http://dx.doi.org/10.1016/j.jep.2007.11.044

HEYDORN, S.; JOHANSEN, J. D.; ANDERSEN, K. E.; BRUZE, M.; SVEDMAN, C.; WHITE, I. R. Fragrance allergy in patients with hand eczema- a clinical study. Contact. Derm., v. 48, n. 6, p. 317-323, june. 2003. http://dx.doi.org/10.1034/j.1600-0536.2003.00133.x

JANNUZZI, H.; MATTOS, J. K. A.; SILVA, D. B.; GRACINDO, L. A. M.; VIEIRA, R. F. Avaliação agronômica e química de dezessete acessos de erva-cidreira [Lippia alba (Mill.) N.E.Brown] - quimiotipo citral, cultivados no Distrito Federal. Rev. Bras. Plantas Med., Botucatu, v. 13, n. 3, p. 258-264, 2011. http://dx.doi.org/10.1590/S1516-05722011000300002

KUMAR, A.; SHUKLA, R.; SINGH, P.; PRASAD, C. S.; DUBEY, N. K. Assessment of Thymus vulgaris L. essential oil as a safe botanical preservative against post harvest fungal infestation of food commodities. Food Sci. Emerg. Technol., v. 9, n.4, p. 575-580, oct. 2008.

https://doi.org/10.1016/j.ifset.2007.12.005

KURITA, N.; MAKOTO, M.; KURANE, R.; TAKAHARA, Y. Antifungal activity of components of essential oils. Agric. Biol. Chem., v. 45, n. 4, p. 945-952, 1981. http://dx.doi.org/10.1080/00021369.1981.10864635

LESLIE, J. F.; SUMMERELL, B. A. The Fusarium laboratory manual. Malden: Blackwell, 2006, 420p. https://doi.org/10.1002/9780470278376

LIMA, A. S.; CARVALHO, J. F.; PEIXOTO, M. G.; BLANK, A. F.; BORGES, L. M. F.; COSTA-JÚNIOR, L. M. Assessment of the repellent effect of Lippia alba essential oil and major monoterpenes on the cattle tick Rhipicephalus microplus. Med. Vet. Entomol., v. 30, n. 1, p. 73-77, mar. 2016.

http://dx.doi.org/10.1111/mve.12140

LIMA, I. O.; NÓBREGA, F. M.; OLIVEIRA, W. A.; LIMA, E. O.; MENEZES, E. A.; CUNHA, F. A.; DINIZ, M. F. F. M. Anti-Candida albicans effectiveness of citral and investigation of mode of action. Pharm. Biol., v. 50, n. 12, p. 1536-1541, nov. 2012. https://doi.org/10.3109/13880209.2012.694893

MA, B.; BAN, X.; HUANG, B.; HE, J.; TIAN, J.; ZENG, H.; CHEN, Y.; WANG, Y. Interference and mechanism of dill seed essential oil and contribution of carvone and limonene in preventing Sclerotinia rot of rapeseed. PLoS ONE, v. 10, n. 7, p. 1-15, july, 2015. https://doi.org/10.1371/journal.pone.0131733

MARCHESE, A.; ORHAN, I. E.; DAGLIA, M.; BARBIERI, R.; DI LORENZO, A.; NABAVI, S. F.; GORTZI, O.; IZADI, M.; NABAVI, S. M. Antibacterial and antifungal activities of thymol: A brief review of the literature. Food Chem., v. 210, p. 402-414, nov. 2016. https://doi.org/10.1016/j.foodchem.2016.04.111 
MAYNARD, L. G.; SANTOS, K. C.; CUNHA, P. S.; BARRETO, A. S.; PEIXOTO, M. G.; ARRIGONIBLANK, M. F.; BLANK, A. F.; ALVES, P. B.; BONJARDIN, L. R.; SANTOS, M. R. V. Chemical composition and vasorelaxant effect induced by the essential oil of Lippia alba (Mill.) N.E. Brown. (Verbenaceae) in rat mesenteric artery. Indian J. Pharmacol., v. 43, n. 6, p. 694-698, nov. 2011. https://doi.org/10.4103/0253-7613.89828

MONTANARI, R. M.; BARBOSA, L. C. A.; DEMUNER, A. J.; SILVA, C. J.; ANDRADE, N. J.; ISMAIL, F. M. D.; BARBOSA, M. C. A. Exposure to Anacardiaceae volatile oils and their constituents induces lipid peroxidation within food-borne bacteria cells. Molecules, v. 17, n. 8, p. 9728-9740, aug. 2012. https://doi.org/10.3390/molecules 17089728

MORO, I. J.; GONDO, G. D. G. A.; PIERRI, E. G.; PIETRO, R. C. L. R.; SOARES, C. P.; SOUSA, D. P. S.; 4, SANTOS, A. G. Evaluation of antimicrobial, cytotoxic and chemopreventive activities of carvone and its derivatives. Braz. J. Pharm. Sci., v. 23, n. 4, 2017. http://dx.doi.org/10.1590/s2175-97902017000400076

OLIVEIRA, D. R.; LEITÃO, G. G.; SANTOS, S. S.; BIZZO, H. R.; LOPES, D.; ALVIANO, C. S.; ALVIANO, D. S.; LEITÃO, S. G. Ethnopharmacological study of two Lippia species from Oriximiná, Brazil. J. Ethnopharmacol., v. 108, n. 1, p. 103-108, nov. 2006. https://doi.org/10.1016/j.jep.2006.04.018

OLIVEIRA, M. M. M.; BRUGNERA, D. F.; CARDOSO, M. G.; GUIMARÃES, L. G. L.; PICCOLI, R. H. 2011. Rendimento, composição química e atividade antilisterial de óleos essenciais de espécies de Cymbopogon. Rev. Bras. Plantas Med., Botucatu, v. 13, n. 1, p. 8-16, 2011. http://dx.doi.org/10.1590/S1516-05722011000100002

OOTANI, M. A.; AGUIAR, R. W. S.; MELLO, A. V.; DIDONET, J.; PORTELLA, A. C. F.; NASCIMENTO, I. R. Toxicidade de óleos essenciais de eucalipto e citronela sobre Sitophilus zeamais Motschulsky (Coleoptera: Curculionidae). Bioscience J., Uberlândia, v. 27, n. 4, p. 609-618, july. 2011.

PEIXOTO, M. G.; BACCI, L.; BLANK, A. F.; ARAÚJO, A. P. A.; ALVES, P. B.; SILVA, J. H. S.; SANTOS, A. A.; OLIVEIRA, A. P.; COSTA, A. S.; ARRIGONI-BLANK, M. F. Toxicity and repellency of essential oils of Lippia alba chemotypes and their major monoterpenes against stored grain insects. Ind. Crop. Prod., v. 71, p. 31-36, 2015. https://doi.org/10.1016/j.indcrop.2015.03.084

PIPER, P.; CALDERON, C. O.; HATZIXANTHIS, K.; MOLLAPOUR, M. Weak acid adaptation: the stress response that confers resistance to organic acid food preservatives. Microbiology. v. 147, 2635-2642, oct. 2001. https://doi.org/10.1099/00221287-147-10-2635

RASOOLI, I.; REZAEI, M. B.; ALLAMEH, A. Growth inhibition and morphological alterations of Aspergillus niger by essential oils from Thymus eriocalyx and Thymus xporlock. Food Control., v. 17, n. 5, p. 359-364, may. 2006. https://doi.org/10.1016/j.foodcont.2004.12.002

SAMPAIO, T. S.; NIZIO, D. A. C.; WHITE, L. A. S.; MELO, J. O.; ALMEIDA, C. S.; MÉRCIA ALVES, M. F.; GAGLIARDI, P. R.; ARRIGONI-BLANK, M. F.; WISNIEWSKI- JUNIOR, A.; SOBRAL, M. E. G.; BLANK, A. F. Chemical diversity of a wild population of Myrcia ovata Cambessedes and antifungal activity against Fusarium solani. Ind. Crop. Prod., v. 86, p. 196-209, mar. 2016.

http://dx.doi.org/10.1016/j.indcrop.2016.03.042

SHUKLA, R.; KUMAR, A.; SINGH, P.; DUBEY, N. K. Efficacy of Lippia alba (Mill) N. E. Brown essential oil and its monoterpenes aldehyde constituents aganst fungi isolated from some edible legume seeds and aflatoxin B1 production. Int. J. Food Microbiol., v. 135, n. 2, p. 165-170, oct. 2009.

https://doi.org/10.1016/j.ijfoodmicro.2009.08.002

SILVA, A. C.; SOUZA, P. E.; RESENDE, M. L. V.; SILVA JR, M. B.; RIBEIRO JR, P. M.; ZEVIANI, W. M. 2014. Local and systemic control of powdery mildew in eucalyptus using essential oils and decoctions from traditional Brazilian medicinal plants. For. Pathol., v. 44, 145-153, 2014. https://doi.org/10.1111/efp.12079 
SOYLU, E. M.; KURT, S.; SOYLU, S. In vitro and in vivo antifungal activities of the essential oils of various plants against tomato grey mould disease agent Botrytis cinerea. Int. J. Food Microbiol., v. 143, n. 3, p. 183189, oct. 2010. https://doi.org/10.1016/j.ijfoodmicro.2010.08.015

TAGNE, A.; KONGSDAL, O.; NGOKO, Z.; THE, C.; MATHUR, S. B. Fusarium pallidoroseum in maize samples of three agro-ecological zones of Cameroon. J. Stored Prod. Res., v. 39, n. 4, p. 367-374, 2003. https://doi.org/10.1016/S0022-474X(02)00031-0

TATEISHI, H; MIYAKE, T.; MORI, M; SAKUMA, Y; SAISHOJI, T. Effect of application timing of metconazole on Fusarium head blight development and mycotoxin contamination in wheat and barley. J. Pestic. Sci., v. 39, n. 1, p. 1-6, jan. 2014. https://doi.org/10.1584/jpestics.D12-077

THRANE, U. Fusarium - Reference Module in Food Science. Enc. Food Microbiology, p. 76-81, aug. 2014. https://doi.org/10.1016/B978-0-12-384730-0.00141-5

VAN DEN DOOL, H.; KRATZ, P. D. A generalization of the retention index system including linear temperature programmed gas-liquid partition chromatography. J. Chromatogr. A, USA, v. 11, p. 463-471, aug. 1963. https://doi.org/10.1016/S0021-9673(01)80947-X

WHITT, J.; SHIPLEY, S. M.; NEWMAN, D. J.; ZUCK, K. M. Tetramic acid analogues produced by coculture of Saccharopolyspora erythraea with Fusarium pallidoroseum. J. Nat. Prod., v. 77, n. 1, p. 173-177, jan. 2014. https://doi.org/10.1021/np400761g 